\title{
Alternative Strategies for Higher Education Provision at TAFE Queensland
}

\section{Paul Wilson}

General Manager, TAFE Queensland Brisbane Region, Queensland, Australia.

\begin{abstract}
Australia's tertiary education and training sector consists of Higher Education, predominantly funded and controlled by the Federal Government, and Vocational Education and Training (VET) where both the Federal and State Governments have policy and funding responsibilities. While there has been increasing funding and stable policy in Higher Education over the past decade there has been significant change in the Australian VET sector in policy and reduced funding at both the Federal and State Government levels. TAFE Queensland, the public VET provider in the state of Queensland, has undergone a huge transformation of its own over this period of extensive policy change. As a result of policy and organisational changes TAFE Queensland has had, and will continue to have to seek alternatives to ensure that students who choose to study at this public provider are able to access higher education courses. This paper outlines various policy change impacts over the past decade and TAFE Queensland's innovative approach to ensuring that quality applied degrees are available to interested students who prefer to study with this major public vocational education provider.
\end{abstract}

Keywords: Policy; competency; applied; change. 


\section{Introduction}

Australia's federal system of government is enshrined in the Australian Constitution. This structure provides for six states and two territories with power being divided between the state governments and the central or Federal Government.

The total population at September 2018 was 25.1 million - with over 50\% in the largest two states of Victoria and New South Wales. Queensland is the third largest by population; the second largest by area; with the third highest population density at 2.97 people $/ \mathrm{km}^{2}$.

The Federal Government has responsibility for developing national policy in areas such as defence and foreign affairs; trade, commerce and currency; immigration; most social services and pensions.

State responsibilities include schools, hospitals, community services, sport and recreation; consumer affairs; police and emergency services; prisons; public works and such like.

The Council of Australian Governments (COAG) structure, that includes all state, territory, and the federal government, acts as the peak intergovernmental forum for Australia.

Higher education responsibility sits with the Federal government who are responsible for support through policies, funding, and programs. Universities and higher education providers are either publicly or privately owned with the majority being publicly owned.

Public university students are eligible for 'Commonwealth Supported Places' (CSP) which in most cases cover the majority of their course fees regardless of the state that they are studying in. All university students are entitled to access the Federal student loan scheme, known as HECS-HELP, that covers an gap fees and thus allows almost all undergraduate students to enter university at zero up front cost.

The regulator for the university sector is the Tertiary Education Quality Standards Authority (TEQSA) which enables the majority of university providers in Australia to be self-accrediting in terms of course offered.

In the Vocational Education and Training (VET) sector there is a joint responsibility between the Federal and State and Territory governments. Each state supports a public owned training organization(s) ${ }^{1}$ and there are many more for profit private training organisations. While there are some Commonwealth VET Student Loans (VSL) arrangements that are common across States, the cost of courses and subsidy provided by

\footnotetext{
1 These are referred to as Technical And Further Education (TAFE) institutes - most states have a single institute except Victoria where there are multiple TAFE institutes
} 
each individual State/Territory can and do vary widely. The impact of the Federal VSL system and differing State/Territory subsidies means that there can be widely different costs of entry to the same course for students who are studying in different states or even across public and private providers in the same state.

The VET sector in Australia operates across a Commonwealth Department of Education managed 10 Level Australian Qualifications Framework (AQF). "The AQF is the national policy for regulated qualifications in Australian education and training. It incorporates the qualifications from each education and training sector into a single comprehensive national qualifications framework. The AQF was introduced in 1995 to underpin the national system of qualifications in Australia encompassing higher education, vocational education and training and school" (AQF, 2019). While the AQF covers up to Doctoral Level very few university courses are actually registered on the AQF.

Qualifications registered within the AQF and the majority of organisations offering them are subject to regulation by the Australian Skills Quality Authority (ASQA) and consist of national training packages, qualifications, courses, and units of competency. There is very limited provision for self-accreditation of courses of study under ASQA regulations.

\section{Major Policy Changes Impacting TAFE Queensland}

Over the last 20 years the Australian VET system has undergone significant transformation through successive changes of government (at Federal and State levels) in response to changing economic and societal needs. A number of significant changes have been made across that decade that has negatively impacted the funding for and therefore participation within the VET sector whilst the university part of the higher education sector has remained mostly unchanged. A precis of the most critical policy impacts are:

- November 2008, COAG endorsed a new Intergovernmental Agreement on Federal Financial Relations (IGA FFR) that included there six new National Agreements (NAs) including one for Skills and Workforce Development (NASWD). At that time there was also agreement reached on new forms of payments to "fund specific projects and to facilitate and/or reward states and territories that deliver on nationally significant reforms”. (SCRGSP, 2009).

The NASWD has at its core a fundamental shift from being driven by the providers (at that stage predominantly State and Territory publicly owned TAFE institutes) to a system notionally driven by the needs of industry and the economy. It was, in every way, leading to a shift from a 'supply-driven' system (i.e. old public TAFE) to a 'demand-driven' system (i.e. fully competitive market) that had 
at its core a very clear marketization signal associated with the pervading neoliberal agenda of most western governments.

- In 2012 the Federal Government committed $\$ 1.7$ b over 5 years to a new National Partnership Agreement on Skills Reform (NPASR) to further the reform of the vocational education and training system - a clear sign to increase the user pays, fully competitive, market led system in the States. This provided an incentive for every state to even more fully open their training market to competition for Government subsidised training places which increased the pressures on TAFE institutes to become more 'commercially' focused. At the core of the NPASR was an 'entitlement' or voucher style funding model to guarantee each eligible citizen access to an entry level vocational education and training qualification though a provider of their choice - this took slightly different forms in each state.

- In 2012 the Australian government removed the cap on government funding available to support university enrolment for eligible undergraduate domestic students attending public universities. The reform permitted public universities to receive Commonwealth support for all eligible students they enrolled, and to choose the course mix they offered which was at direct odds to the market based reforms occurring in the VET sector.

- In 2016 the Federal Government announced that the existing VET FEE HELP loan system was to be scrapped due to rorting of the system by a large number of private providers (Dodd, 2016). It was replaced by the VET Student Loan (VSL) system that reduced the amount of funding for students and increased the underlying cost of entry to VET study - particularly at the Diplomalevel.

- In 2017 the Federal Government reinstated capped university places (i.e. the number of CSPs) at 2017 levels for two years.

- In the 2017/18 Budget the Federal Government announced a review of the AQF. The AQF report was published in October 2019 and proposes a significant review of the AQF which includes a significant structural change from the existing ten levels to eight bands of knowledge and six levels of skills (Noonan, 2019)

- In 2019 COAG agreed to a process to reform the VET sector and the Skills Council has developed a VET Reform Roadmap which has developed to a consultation draft. 


\section{Policy Impacts}

Historically, affordability and accessibility of TAFE to students and business has been intrinsically linked to the level of government funding provided to certain priorities. Affordability and accessibility were impacted by the transformation of the Australian VET system to a managed market model. Priority qualifications under the national training entitlement meant that other programs attracted less government funding and therefore the cost to students wanting to undertake lower priority courses increased. This had the unintended effect of limiting training for low socio-economic and/or disadvantaged groups and also contributed to higher deferred debt through income contingent loan schemes.

Figure 1 clearly shows that marketisation through policy changes drove down government investment (i.e. combined Federal and State) in VET which in turn led to increased costs for students and thus further decreased TAFE enrolments. This led to decreased VET investment over the period 2011/12 to $2015 / 16$ - both in real terms and even more so in comparison to the increase in university based higher education where the introduction of uncapped demand driven funding led to a significant increase in enrolments and thus funding. The proportion of private training providers seeking registration each year has risen steadily over the past 10 years and in 2015 was almost 95\% (Korbel \& Misko, 2016) of the total providers. The total number of VET providers has been approximately steady over the past decade at around 4,500 across Australia - but this figure is high compared to other OECD countries when proportioned across the total population (ibid).

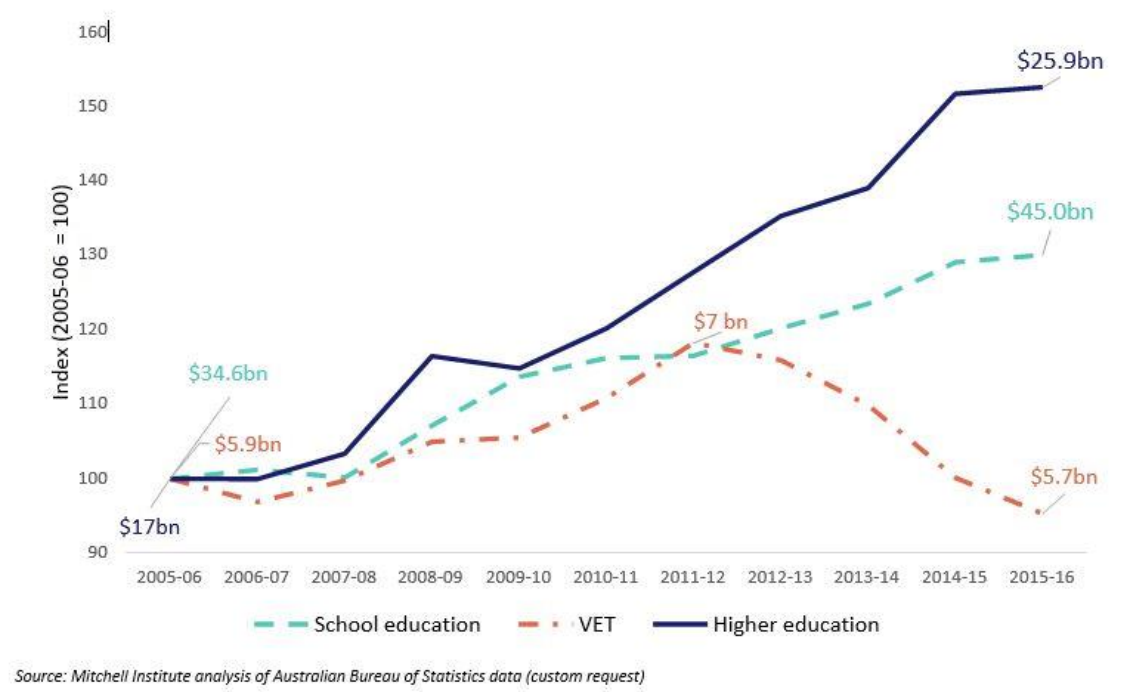

Figure 1. Government Investment in Education. 
The challenge nationally, and for VET sector stakeholders and clients, is the propensity and ability for clients to pay fee increases for services that are no longer prioritised for government investment. This issue is a natural consequence of shifting priorities for government funding in a fiscally restrained environment.

The initial years (2014 to 2017) of TAFE Queensland's existence was in the context of fundamental change in the VET sector across Australia. The Federal student Loan system VET FEE HELP (VFH) was established in 2008 and grew from \$25 million in its first year to $\$ 1$.3billion by 2013 . This was a direct result of changes in $2011 / 12$ that removed a requirement for VFH courses to hold articulation agreements with a Higher Education Provider and other changes that encouraged greater private sector provider access to the scheme. Unfortunately, some private RTOs saw this as an opportunity and over the next four years the annual Commonwealth loan amount for diploma level courses blew out to $\$ 2.9$ billion.

It was identified that many of the students were falsely enrolled through incentives and the completion rates for some colleges were as low as $8 \%$. In late 2016 the VFH scheme was halted and a much more controlled VSL scheme was introduced for much smaller number of providers from January 2017 onwards (Dodd, 2016). As with so much central policy work the unintended consequences of the change has negatively impacted on the remaining providers including TAFE Queensland where courses subject to the new VSL system have seen enrolment reductions in Diploma courses approaching 30\% over the past twoyears.

In 2018 the Federal Government instigated an expert review of Australia's vocational education and training system. This review was undertaken by the Honourable Steven Joyce, a former Minister of the New Zealand Government. Amongst many other findings it was identified that "Funding system inconsistencies between States and Territories, between States, Territories and the Commonwealth, and between the VET and higher education sectors - were all identified by Review participants as creating unnecessary complexity and inequity" (Joyce, 2018). This is a major concern for TAFE Queensland whose aim is to provide seamless pathways for all students to reach their desired learning goals.

\section{TAFE Queensland Reforms}

The Queensland State Government introduced legislation in 2012/13 that included full open competition within the VET sector from 1 July 2014 and a concurrent ambitious reform of the Queensland TAFE sector. At that time, the sector consisted of 13 semi-independent TAFE Institutes with two operating as Statutory Bodies. The legislation established TAFE Queensland as a new single entity Statutory Body that commenced operations in July 2014 with six semi-autonomous regional bodies. On establishment of the new TAFE Queensland 
entity there were some 50 locations across Queensland; just over 5,000 FTE employees; servicing some 125,000 students each year. The new TAFE Queensland was the largest VET provider in Queensland by a significant margin and was the second largest in Australia after the recently reformed TAFE New South Wales.

Prior to the reforms each TAFE institute offered a range of VET diplomas that provided pathways into university courses with varying credit arrangements. Only Southbank TAFE offered its own TEQSA approved Associate Degree program that allowed students to access student loans under the FEE HELP scheme. Under the new TAFE structure it was decided to investigate offering degrees to enable students who wished to continue their study by providing pathways from diploma to degree without having to change provider.

\section{Higher Education delivery at TAFE Queensland}

During 2014 two applied degree programs were developed by staff within TAFE Queensland that subsequently gained TEQSA accreditation and approval. These were the Bachelor of Dental Prosthetics and the Bachelor of Creative Arts and Entertainment.

The Bachelor of Dental Prosthetics degree was specifically developed to meet the needs of the dental profession and was subsequently accredited by TEQSA. This program recently attained Australian Dental Professional Association accreditation following graduation of the first cohort of students in 2018.

It was also recognized that the Bachelor of Creative Arts and Entertainment was unlikely to be supported by TAFE students due to the high entry cost to them as it was not eligible for CSP. Through 2015 negotiations commenced with a number of potential university partners to identify a source of CSP places for TAFE students.

The University of Canberra (UC) had a desire to increase its student cohort and was also keen to expand its creative industries program offerings. A formal agreement was reached to allow UC to offer the contemporary TAFE Bachelor of Creative Arts as UC branded and accredited courses. In return agreement was reached with UC that TAFE could offer those UC courses at its Southbank Campus taught by TAFE teaching staff with students enrolled as UC students thus allowing them access to UC's CSPs. Furthermore, the arrangement recognized that the TAFE Diplomas were of a standard that allowed the students to gain advanced standing of up to one year. This meant that students could enroll in a TAFE Diploma, pathway into the second year of a UC degree, and in three years graduate with two qualifications.

While there was good take up from students in the creative arts area within the large urban Southbank Campus of the Brisbane region similar options for other course areas such as business and ICT were not as easily developed. It became readily apparent that internal 
champions at both entities were essential for this novel partnership opportunity to be formalised and made operational.

Through 2016 the attractiveness of the UC partnership model was identified by other smaller regions within TAFE Queensland. A 'hub and spoke' model was implemented to provide a way of enabling students from smaller cohorts in three regions - namely Gold Coast, East Coast, and North. During 2016 and 2017 enrolments were accepted in these regions but due to the low numbers of potential students wanting to take up this option coupled with a lack of expertise in higher education delivery this model ceased to operate in 2018 with those regional students being taught out through 2019/20.

With the re-introduction of caps for university students from January 2018 UC identified that it wished to re-evaluate the existing arrangements. Negotiations continued over the next 18 months and in late 2019 a new UC partnership has been signed. This new agreement focuses on the five creative arts majors that have formed the backbone of enrolments for TAFE students and is constrained to the Southbank campus of the Brisbane region.

Over the 2018/2019 period negotiations have also continued with other universities with other regions. This will allow TAFE Queensland to add diversity to the CSP supported degree offerings that can be made available to our students that recognizes the strengths of individual regions and their partner universities. As we enter 2020 there is an emerging multi-partner model that provides a much wider range of opportunities for our students:

- TAFE Queensland Bachelor of Dental Prosthetics and Associate Degree in Engineering at the Southbank Campus, Brisbane region

- UC Creative Arts at the Southbank Campus

- Southern Cross University Music and ICT courses at the Coomera Campus, Gold Coast region.

- Federation University Applied Management at Southbank Campus.

- Central Queensland University Creative Arts at the Cairns Campus, Northregion.

- Central Queensland University Cyber Security and Robotics at the Southbank Campus.

With an innovative approach to partnerships TAFE Queensland has made it possible for students to commence with a Diploma program and exit with a Bachelors degree with the same minimal entry costs as students who choose to enter university directly - something that few other TAFE institutes across Australia are able to emulate. 
The VET Reform Roadmap Consultation Draft (2020) proposes, amongst other objectives, a "stronger alignment and integration between VET and Higher Education" sectors, as previously outlined in the AQF review, that will allow VET students to access Commonwealth loans to study applied degrees offered by TAFE institutes. This will make the cost of entry lower and ensure that students studying degrees at TAFE Queensland are not disadvantaged c.f. those who enter universities.

This will provide opportunities for TAFE Queensland, a known high quality VET institute, to continue to develop its own higher education programs to allow students who chose to pathway from entry level certificates to degrees at the one quality provider. By working with university providers through the change period TAFE Queensland is building its own expertise to be ready for the new tertiary education framework in Queensland, Australia.

\section{References}

AQF, www.aqf.edu.au, January 2019.

Dodd, T; It's no surprise the VET FEE HELP system was rorted; Australian Financial Review, Oct 2016; https://www.afr.com/policy/health-and-education/its-no-surprisethe- vet-feehelp-scheme-was-rorted-20161005-grv1nk

Joyce, S., (C) Commonwealth of Australia, Department of the Prime Minister and Cabinet, Strengthening Skills, 2019.

Korbel, P \& Misko, J 2016, VET provider market structures: history, growth and change, NCVER, Adelaide.

Noonan, P., Review of the Australian Qualifications Framework Final Report 2019, Canberra

SCRGSP (Steering Committee for the Review of Government Service Provision) 2009, Report on Government Services 2009, Productivity Commission, Canberra.

VET Reform Roadmap Consultation Draft, Skills Senior Officials network, 2020, https://docs.employment.gov.au/documents/vocational-education-and-training-vetreform-roadmap-consultation-draft 